\title{
PEDAGOGICAL CONDITIONS OF CIVIC COMPETENCE FORMATION OF FUTURE PRIMARY SCHOOL TEACHERS IN PEDAGOGICAL COLLEGE
}

\author{
Hritchenko T. Ya., Maidanyk O. V.
}

\section{INTRODUCTION}

The professional development of a primary school teacher begins in a higher educational establishment. Here he is formed a system of personally significant and civic values, professional regulations; ideas about the goals, pedagogical activity content and essence. In the structure of the new generation teacher's personality the leading place should belong to civic competence. It is an indicator of his socio-professional maturity and will serve as a guide in educating the pupil's personality in the future. Thus, the requirements for the civic competence formation of future primary school teachers in higher educational establishments, in particular, pedagogical colleges, are growing.

The initial conceptual principles of individual's civic competence formation are confirmed in the laws of Ukraine "On Education", "On Higher Education", "On Child Protection"; Concept of civic education development in Ukraine and Concept of state policy realization in the field of general secondary education reforming "New Ukrainian school", etc.

In particular, the Concept "New Ukrainian School" states that in accordance with the basic Law "On Education" among the key competencies for the new Ukrainian school social and civic competencies are defined ${ }^{1}$.

K. Bakhanov, N. Bibik, I. Yermakov, O. Lebedev, O. Ovcharuk, O. Pometun, O. Sukhomlynska and others studied the formation of civic education; R. Artsyshevsky, T. Bakka, P. Verbytska, O. Kucher, T. Ladychenko, M. Mykhaylichenko, V. Orzhekhovsky, M. Ragozin, S. Ryabov, I. Taranenko, K. Chorna, O. Shestopalyuk and others studied the problem of person's civic competence formation.

At the same time, the source base analysis gives reasons to claim that the problem of civic competence formation of future primary school teachers in the pedagogical college has not been the subject of a special pedagogical study.

The urgency of the problem is confirmed by a number of contradictions between:

\footnotetext{
${ }^{1}$ Нова українська школа: Концепція реалізації державної політики у сфері реформування загальної середньої освіти. URL: http://mon.gov.ua/\% 202016/12/05/konczepcziya (дата звернення: 03.08.2017).
} 
- social needs of the country in the primary school teachers training, able to qualitatively form the personality of Ukrainian citizen in their future professional activity, and insufficient consideration of these requirements in the educational process of the pedagogical college;

- the need to implement state strategies for a competency-based approach in modern education and the undeveloped theory and appropriate training methods of future primary school teachers in the pedagogical college;

- requirements for the quality of the civic competence formation process of future primary school teachers in the pedagogical college and the lack of scientifically pedagogical conditions.

The urgency of the problem, its theoretical and practical significance and insufficient scientific development, as well as the need to overcome these contradictions led to the research topic choice.

The aim of the study is theoretical substantiation of pedagogical conditions of civic competence formation of future primary school teachers in pedagogical college and experimental check of their efficiency.

The following research methods were used to achieve the goal and solve the outlined tasks:

- theoretical - analysis of philosophical, sociological, psychological and pedagogical, special literature for comparison of different views on the chosen research problem, systematic analysis to substantiate the pedagogical conditions for the civic competence formation of future primary school teachers in the pedagogical college;

- empirical - diagnostic (questionnaires, interviews, testing, selfassessment, expert assessment), observational (direct, indirect and long-term pedagogical observation), creation of socio-pedagogical situations to study the student behavior peculiarities; pedagogical experiment to identify experimental work effectiveness;

- mathematical statistics methods - quantitative analysis, Student's tcriteria to test the statistical hypothesis about the difference between the average levels values of civic competence of future primary school teachers in the experimental and control groups.

The main material presentation. We consider the civic competence of a primary school teacher as a key professional competence component; multivariate, holistic, dynamic, integrated formation of the specialist personality, affirming the civic and life position, individual's civic maturity and socially useful activities, as well as the need to form the primary school pupils' citizenship as a priority socio-moral value.

Future teachers' civic competence formation should be considered as an important component of professional training system, which allows to implement social and educational activities in the socio-educational college space.

To ensure an effective impact on the procedural side of the educational process in the pedagogical college, aimed at the civic competence formation 
of future primary school teachers, in the experimental study we have identified the following pedagogical conditions:

- improving the process content of civic competence formation of future primary school teachers;

- innovative teaching technologies application in the process of civic competence formation of future primary school teachers;

- social and educational space organization as a factor of civic competence formation of future primary school teachers.

\section{Content improving in the process of forming civic competence of future primary school teachers}

Implementing the first pedagogical condition, we have improved the content of educational disciplines of professional and practical training and humanitarian, socio-economic training, the content of which reveals the problem under study from the point of view of various scientific fields.

In particular, one of the important tasks set for students during the course "Introduction to the specialty" study is the professional competence acquisition and teacher's general culture development. Therefore, we consider it expedient to involve civil issues elements in this course. In particular, to the following topics: "Development dynamics of the educational system of Ukraine", "Information and communication technologies and "eternal" values of life and upbringing", "Professional portrait of a teacher-citizen".

During the study of this course, college teachers conduct a survey on the problems of modern students' attitudes to civic values. This contributes to the awareness and better understanding of such phenomena as morality, spirituality, citizenship, identity, patriotism, civic activism, etc.

The purpose of the discipline "Pedagogy" is students' mastering a holistic system of theoretical knowledge of pedagogy as a human education and training science, the formation of ability and readiness for their use in professional and pedagogical activities.

In the course of pedagogy the problem of civic competence formation should be considered in the framework of classes devoted to the purpose and main directions of education. Taking into account that the course "Pedagogy" includes two sections - didactics and theory of education, we have considered it most appropriate to supplement the elements of our civic competence formation system into the topics of the second section.

In the process of studying the theory of education, special attention is paid to:

- civic ideas in the framework of the most important concepts and theories of personality development;

- civic education, its dynamics and trends in modern conditions; 
- goals, content, forms and methods of civic competence formation in a modern school;

- determining the role and place of civic competence formation in the holistic educational process;

- formation on the basis of studying the ideas of various scientific schools on civic competence, as a component of modern teacher's professional competence, etc.

In "Theory of education" section a special place is given to the study of topics devoted to the individual's spiritual development, the educational process content, the education methods, the school educational system, school and family education relationship.

The curriculum of the discipline "History of Pedagogy" provides for such topics study: "Education and upbringing in the ancient world civilizations", "Pedagogical thought in Ukraine in the early twentieth century", "Pedagogical thought in Ukraine in the nineteenth - early twentieth century". We supplemented their content with the following questions: "Greek and Roman traditions of civic education", “A. Makarenko's approach to pupils' civic competence formation in the team", "Civic position of the Ukrainian intellectuals in the struggle for national school", "Students civic competence formation in a modern national school".

The program of the discipline "Methods of teaching integrated course "I explore the world" involves clarifying the relationship between the environment, human and society. In order to form the professional and civic competencies of future professionals, the topic "Pupils civic competence formation in the lessons "I explore the world" has been introduced into the curriculum.

Studying the course "Political Science" allows students to form knowledge about political development patterns, power nature and its types; ideas about political norms; the problem of powers separation; the role of political parties, movements, associations, etc.

However, nowadays, from the point of view of civic competence formation of future primary school teachers, the following issues are of special importance:

- the ratio of morality and political decisions,

- the role of city self-government,

- the relations between political parties,

- the civil society development and features of its formation in Ukraine.

Therefore, we believe that the urgent task of political science classes should be to form in students a critical attitude to any ideologies and political currents, political parties' programs and an adequate idea of civil society as a social space. A space in which there are various organizations and associations that are relatively independent of state power, capable of conducting sociopolitical dialogue both with state bodies and with each other. 
The thematic material of the course "History of Ukraine", which determines the position of Ukraine in the period of political and economic society liberalization (1953-1964) and in the modern world has been supplemented by questions that reveal the dissent impact on civic consciousness formation of Ukrainian society, the role of civic education in the national educational system of Ukraine.

The program of the discipline "Fundamentals of Philosophical Knowledge" provides students acquaintance with the humanistic content of the philosophy history and development. We believe that the study of future primary school teachers' views on the concepts of "citizen" and "civil society" in the philosophical thought of Ukraine in the XIX century will contribute to the formation of their civic position.

The study of the discipline "Sociology" in the pedagogical college is aimed at solving an important task - the formation of a social personality, a personcitizen. We believe that this is a necessary condition for the formation of legal, democratic, civil society and future teachers' sociological thinking.

However, in the process of mastering sociology, future primary school teachers, in our opinion, acquire, first of all, the knowledge necessary for the sociological thinking formation, and insufficient knowledge to form their civic competence. In this regard, the sociology curriculum is supplemented with practical civics classes:

- "Organization of individual's education and self-education";

- "Formation of civic consciousness of the future primary school teacher";

- "Intelligence, morality and creativity in the teacher-citizen's professional activity."

To enrich the content of Ukrainian language teaching methods with civic concepts, the topic "General issues of Ukrainian language teaching methods" has been supplemented with material that highlights the importance of Ukrainian as a major factor in the formation of communicative competence and civic consciousness of future primary school teachers.

To the content of the discipline "Fundamentals of Law" we have expediently added issues that characterize civil society development in Ukraine, its history and modernity.

Thus, an important condition for the effective civic competence formation of future primary school teachers in the pedagogical college is the integrated use of disciplines' civic potential, enriching their content with concepts, ideas, theories, facts that reveal the essence of civic values and beliefs.

\section{Application of innovative teaching technologies in the process of civic competence formation of future primary school teachers}

The implementation of our improved content of civic competence formation of future primary school teachers in the pedagogical college 
requires the use of innovative pedagogical technologies, creative search for new or improved concepts, principles, approaches to education. The second pedagogical condition we have chosen is the innovative learning technologies use in the process of civic competence formation of future primary school teachers in the pedagogical college.

The need for innovative orientation of pedagogical activity, as well as education at the present stage of society and education development as a whole have been caused by a number of circumstances, namely:

- socio-economic transformations and scientific and technological progress, necessitating a radical overhaul of the higher educational system. Innovative orientation of teachers and students involves pedagogical innovations, its creation, assimilation and use;

- strengthening educational content humanization, the introduction of new specialties, new subjects, elective courses require a constant search for new organizational forms, learning technologies. As a result, teacher's role and importance as a generator of pedagogical ideas is growing;

- changing the nature of teachers' attitudes to the very fact of assimilation and application of pedagogical innovations. Innovative activity was mainly limited to the use of recommended above innovations. Today, innovative activities are becoming more selective, increasing the degree of teacher's freedom; there is an entry of higher educational institutions into market relations, there are new types of private educational institutions, which creates a real situation of their competitiveness ${ }^{2}$.

The analysis of scientific researches and publications testifies that I. Dychkivska, O. Dubasenyuk, N. Dudnyk, V. Zaitsev, S. Kashlev, M. Klyap, O. Komar, V. Luhovyi V. Morozov, G. Pyatakova, L. Rondyak, V. Rudenko, G. Selevko, M. Chepil, D. Chernilevsky and others have been engaged in questions of innovative technologies introduction to the university training. Scientists claim that the purpose of innovative learning technologies is to increase the educational process efficiency in the higher educational institutions and obtain a qualitatively new result.

Among the innovative teaching technologies that will most effectively contribute to the civic competence formation of future primary school teachers, the following technologies have been singled out: problem-based, interactive, project-based learning; development of critical thinking and multimedia.

Let's move on to the characteristics of our chosen technologies in accordance with our study objectives.

The analysis results of scientific works of V. Kudryavtsev, M. Makhmutov, V. Okon, G. Selevko show that problem-based learning is a type of

2 Дубасенюк О. А. Інноваційні навчальні технології - основа модернізації університетської освіти. Освітні інноващійні технологї̈ у процесі викладання навчальних дисииплін. Житомир, 2004. С. 3-14. 
developmental learning, the content of which is represented by a system of problem-solving tasks of different complexity levels. In solving problems process, students learn new knowledge and action methods. As a result, their creative abilities, productive thinking, cognitive motivation, emotional intelligence and other personal qualities are formed. It is carried out by initiating the student's independent search for knowledge, educational material problematization. And also on the basis of the teacher's principles use of problem-solving, accessibility, motivation, interdisciplinary connections, etc.

Problem-based learning is focused on future teachers' discovery of subjectively new knowledge and skills by solving theoretical and practical problems. It is based on consistent and purposeful creation of problem situations in the form of educational tasks and questions.

"Problem situation is a mental state of difficulty that arises due to the inability to explain the fact or solve the problem with the available knowledge and skills. It can be done by setting a task, question, demonstration of experience, mechanism, material from the press or students' personal observations" ${ }^{3}$. They encourage future professionals to search, develop general abilities, the ability to find answers to questions. It contributes to the development of their professional skills and civic culture.

In order to form the civic competence of future primary school teachers in the study of humanities and socio-economic training, as well as professional and practical training, the following forms of problem-based learning have been used:

- seminars, structured discussions and problem-based discussions (based on discussion activities);

- problem lecture, problem seminar, excursion class, problem solving class, consultation class (traditional classes with new aspects);

- auction class, court class (non-standard classes), etc.

According to the State Standard of Primary Education and Curricula, an essential component of primary school educational process is a project activity. Creating projects contributes to the formation of students' skills of research and independence; develops their intellectual abilities.

In this work, a teacher needs to help pupils in finding information sources, to be a partner and work coordinator. Therefore, we believe that every primary school teacher should have their own project technology. $\mathrm{He}$ must plan, anticipate possible difficulties on the pupils' part during the new material assimilation, find methods and techniques for overcoming them, navigate in the information space. The educator must teach pupils to acquire knowledge independently and use it to solve life situations and so on.

According to scientists, project technology is a system of educational and cognitive techniques that allow to solve a problem through pupils'

\footnotetext{
${ }^{3}$ Галузяк В.М., Сметанський M.I, Шахов В.І. Педагогіка : навчальний посібник. 2-е вид. випр. і. доп. Вінниця, 2003. 416 с.
} 
independent, collective, interactive actions and mandatory work results representations ${ }^{4}$.

Based on theoretical provisions and practical experience and in order to form the civic competence of future primary school teachers in the pedagogical college, we have developed some educational projects, among which it is worth highlighting:

- group or personal (individual) projects in which students' educational activity dominates;

- information project (issue of the newspaper "Schoolboy", materials selection "Historical life of ancient Vinnytsia");

- creative project (free author's approach to solving a certain problem ("School of the future", "Human and civil rights", "Civil society and democratic state", "Ukraine as an independent democratic state", "People and the human in Lina Kostenko's historical novel "Marusya Churai"));

- role project (literary, historical, business role-playing games ("We are citizens of Ukraine", "The world and a man in the poem by Ivan Franko "Moses")).

- research (research of a certain problem according to all the rules of scientific research ("Outstanding Ukrainians", "From an intelligent person to a spiritual person", philological study "Ukrainians: where are we and our language");

- practice-oriented (textbook "Native Vinnytsia". Local lore material for work in the classroom and in extracurricular activities with primary schoolchildren).

The meaning of civic education is to promote awareness of the vital need for the individual's democracy. It is designed not only to form an understanding of social problems. Its meaning is to affirm a conscious civil position, to ensure the requirement to be heard and needed by society. We believe that this goal can be achieved through the critical thinking technology. It exists simultaneously with logical, analytical, creative and other types of thinking. And it differs from them in that at the end it forms not only the ability to consciously analyze, draw their own conclusions, see the problem in various ways, but also in individual's position and spiritual content ${ }^{5}$.

During civic competence formation of future primary school teachers by means of critical thinking it is expedient to single out the following tasks:

- awareness of the relationship between the ideas of individual thinking freedom, human rights and its civic responsibility;

- formation of responsible behavior and civic consciousness;

4 Терещук А. І., Дятленко С. М. Методика організації проектної діяльності старшокласників 3 технологій: метод. посіб. для вчителів; навч. прогр., варіат. модулі. Київ, 2010. 128 с.

${ }_{5}^{5}$ Києнко-Романюк Л.А. Розвиток критичного мислення студентської молоді як загальнопедагогічна проблема : дис. ... канд. пед. наук. Київ, 2007. 209 с. 
- affirmation of humanistic morality and respect formation for such values as freedom, equality, justice;

- adhering to the following problems: confidence in living together and cooperating in civil society, willingness to take on the truth, the ability to resolve conflicts, adhering to the people's democratic principles;

- ability to defend one's personal position, find new ideas and critically analyze problems, rethink actions and arguments, etc ${ }^{6}$.

Characteristic features of the civic competence formation process, aimed at future specialists' development in critical thinking, are:

- use of cognitive and problem-solving tasks in classes on socioeconomic disciplines;

- development of future specialists' opinions and making objective decisions;

- ability to receive and use information, develop criteria for making judgments about people, situations, decisions, make decisions about collective management and social problems, etc.

Thus, the use of innovative technologies in the educational process of the pedagogical college contributes to the humanization and socialization of future primary school teachers, influences their personal development (interests, needs, values), providing freedom of thought, choice, selfconfidence etc.

\section{Socio-educational space as a factor in the formation of civic competence of future primary school teachers}

Taking into account all the above mentioned, the third pedagogical condition that we have defined is the organization of socio-educational space as a factor in the civic competence formation of future primary school teachers in the pedagogical college.

In the scientific and pedagogical literature, "educational space" is characterized as "existing in society" place, where many relationships and connections are subjectively set, where special activities of different systems (state, social and mixed) are realized for the individual's development and socialization ${ }^{7}$.

The problems of educational space have been covered by A. Artyukhina, A. Bondarevska, O. Leonova, Y. Manuilov, L. Redko, A. Tsymbalaru, G. Shevelyova, I. Shendryk and others.

The definition of "educational space" scientists describe as:

6 Кацова Л.Г. Організація педагогічної практики студентів в умовах інноваційного режиму школи. Педагогічні науки. Вип. 33. Херсон, 2003. С. 269-275.

${ }^{7}$ Основні орієнтири виховання учнів 1-12 класів загальноосвітніх навчальних закладів України. Програма. Авторський колектив проекту: І. Д. Бех (кер. проекту та автор концептуальних засад) та ін. Тернопіль, 2008. 80 с. 
- pedagogical reality, which declares itself by the coexistence of Man and the World through education ${ }^{8}$;

- interconnected lines, degrees and modules of educational situations that promote student's activity, initiative and independence development ${ }^{9}$;

- the result of the subject's environment assimilation through a specially organized specific human activity ${ }^{10}$.

Properly designed and created educational space, interacting with the social environment, becomes a significant factor in the students' personal development.

We interpret social and educational space as a single organized and structured system that promotes the development of:

- positive motivation to form their own civic competence;

- interest in public activities and participation in public affairs;

- need for interpersonal interaction in social activities;

- respect for civic values and legal framework of the state and law;

- need for self-education in the process of civic competence formation;

- readiness for self-realization and self-improvement of professionally significant personal qualities for junior schoolchildren's citizenship education.

The social environment is directly connected with the pedagogical environment in the pedagogical college. It is also one of the educational space components in the educational institution. The social environment is aimed at meeting the needs and interests of the individual in accordance with universal and national values. In the conditions of a comfortable social and psychological climate, cooperation, trust and humanism there is future expert's self-realization, upbringing of his professional and civic qualities.

Student self-government is an important factor in the civic activity formation of student youth. Ukrainian scholars interpret it as a process of students fulfilling their responsibilities and initiatives with their own efforts and in cooperation with the administration. Student government provides work through the participation of young people in solving issues of the student community and provides opportunities to realize the rights to freedom ${ }^{11}$.

8 Леонова О. Образовательное пространство как педагогическая реальность. Alma таtеr (Вестник высшей школы). 2006. № 1. С. 36-40.

9 Редько Л.Л., Чумичова Р.М. Теоретические подходы и проектирование образования в современных условиях. Ставрополь, 1996. 24 с.

10 Шендрик И.Г. Теоретические основы проектирования образовательного пространства субъекта. Екатеринбург, 2006. 198 с.

11 Потопа К. Л. Соціально-педагогічні умови організації студентського самоврядування у вищих навчальних закладах : дис. ... канд. пед наук. Київ, 2006. 193 с. 
Examining the concept of "self-government", we have found that it is defined as a form of "democracy", as a method of governance based on organization, self-regulation and initiative and does not allow compulsion ${ }^{12}$.

Self-government is based on the same principles as democracy: priority of the majority, formal equality, free expression of interests, generally accepted rights and responsibilities, a combination of representation and will expression. In higher educational institution, student government can be seen not only as a tradition, but as a mechanism for building a model of education management in general, a way to establish the democratic principles of the future elite ${ }^{13}$. The main purpose of self-government is the education of socially valuable qualities capable of forming students' life and civic position, to prepare them for participation in the democratic society management.

One of the student work forms is student clubs and studios. They unite young people, acquaint them with various achievements of science and culture, help them to define themselves in relation to their abilities and needs, to realize themselves in public life.

The leading role in self-determination and acquisition of social experience by future teachers, college student community members belongs to charitable activity. It is carried out for the welfare of people who are in a difficult situation due to life circumstances and need some help. Involving students in this type of work is one of the ways to form their civic position and solve acute social problems without the government participation. A significant place in charitable activities is occupied by the volunteer movement.

Among the charitable activity areas of pedagogical colleges should be singled out:

- historical and local lore work (students' involvement in the study of native land history and traditions);

- environmental protection (environmental issues coverage in the media, work organization on landscaping, etc.);

- charitable activities (holding charity concerts and events for those who are in hospitals, boarding schools for orphans);

- assistance in the social adaptation of people with special needs;

- honoring war and labor veterans, JFO soldiers;

- toys and books collection for orphanages and social rehabilitation centers for children;

- volunteering ideas popularization, etc.

12 Швидкий С., Ступак О. Становлення та розвиток студентського самоврядування в України. Рідна школа. 2014. № 3. С. 20-23.

${ }^{13}$ Студентське самоврядування в Україні / Упоряд. Н. Демчук, Л. Кудіна. Київ, 2004. $60 \mathrm{c}$. 
Thus, the socio-educational space of the pedagogical college is focused on the development of civic culture and civic consciousness of future primary school teachers. It is able to provide a humanitarian combination of students' professional development with the formation of high moral traits of a Ukrainian citizen; improving the patriotic education of student youth; upbringing of socially active personality, capable of self-improvement and self-realization, etc.

Thus, the defined pedagogical conditions, complementing and mutually stipulating each other, have become the determining factors promoting formation of expert's specified quality.

\section{CONCLUSIONS}

In our research, based on scientific sources analysis, we have identified the components of civic competence of future primary school teachers value, cognitive, behavioral, reflective. The criteria, we have included, are motivational-value, knowledge-informational, organizational-activity, subject-evaluation. The civic competence level of future primary school teachers can be high, medium or low.

Research and experimental work on the civic competence formation of future primary school teachers in the pedagogical college was carried out during five stages: exploratory, ascertaining, design, formative, and diagnostic evaluative.

At the exploratory stage of research and experimental work, a theoretical problem analysis in the scientific and pedagogical literature and educational practice was carried out. As a result, the choice of the research direction was substantiated, its object, subject, purpose and tasks were defined, basic theoretical positions were identified and formulated. The content of the pedagogical category "civic competence of future primary school teachers" was also specified.

At the ascertaining stage, the pedagogical colleges activity was monitored in the effectiveness context of the civic competence formation of future primary school teachers. It included institutions that formed the experimental study basis. The content analysis of the civic competence formation of future primary school teachers in the educational process of the pedagogical college and program-methodical support of the specified activity type was carried out.

During the design stage the model of civic competence formation of future primary school teachers in the pedagogical college was substantiated and developed.

The formative stage of research and experimental work was connected with checking the influence of the developed theoretical and methodical materials on the quality of the studied phenomenon formation in students of the experimental group and its comparison with students of control groups. 
The diagnostic and evaluation stage of the experimental work provided:

- identification and assessment of civic competence formation levels in students of experimental and control groups according to certain criteria and indicators on the basis of the developed tasks system;

- evaluation and comparison of the obtained empirical data for qualitative and quantitative analysis and generalization of research results;

- working off conditions and adequate means selection for their further implementation in the educational practice of the pedagogical college.

The generalized study results of the civic competence formation levels of future primary school teachers at the ascertaining and formative stages of the experiment are presented in the table 1 and in the figure 1 .

Table 1

Dynamics of civic competence formation levels of future primary school teachers (according to consolidated data of ascertaining (AE) and formative (FE) experiments), \%

\begin{tabular}{|c|c|c|c|c|c|c|}
\hline \multirow{2}{*}{ Levels } & \multicolumn{3}{|c|}{ Control group } & \multicolumn{3}{c|}{ Experimental group } \\
\cline { 2 - 7 } & $\mathrm{AE}$ & $\mathrm{FE}$ & Dynamics & $\mathrm{AE}$ & $\mathrm{FE}$ & Dynamics \\
\hline High & 13,2 & 13,7 & $+0,5$ & 12,9 & 27,3 & $+14,4$ \\
\hline Medium & 42,4 & 44,9 & $+2,5$ & 41,8 & 58,7 & $+16,9$ \\
\hline Low & 44,4 & 41,4 & $-3,0$ & 45,3 & 14,0 & $-31,3$ \\
\hline
\end{tabular}

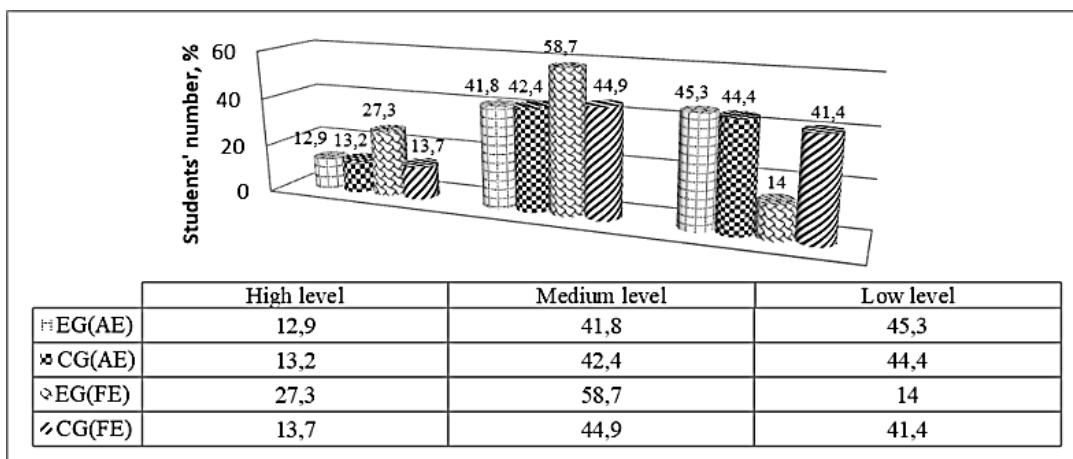

Fig. 1. Distribution of future primary school teachers according to the civic competence formation levels at the ascertaining and formative experiment stages

Comparative analysis of diagnosing results of specialists' quality at the ascertaining and formative stages showed significant differences in the civic competence formation levels. It should be noted that the pedagogical conditions introduction within the simulated educational process made it possible to increase the civic competence level in the students of the experimental group. 
Verification of the obtained data reliability and significance of experimental work was carried out using mathematical statistics methods. The arithmetic mean values of the obtained data, the values of the mean standard errors, variances, standard deviations have been calculated. A one percent probability level has been specified $(\mathrm{p}=0,01)$. Statistical analysis has been performed using an Excel spreadsheet using built-in statistical functions.

To calculate the significant difference between the civic competence formation levels in students of the experimental and control groups on the ascertaining and the formative experiment stages used Student's t-test for independent sampling.

$$
t=\frac{\left|M_{2}-M_{1}\right|}{\sqrt{m_{1}^{2}+m_{2}^{2}}},
$$

where $M_{1}, M_{2}$ are arithmetic mean values of variables in groups before and after the experiment;

$m_{1}{ }^{2}, m_{2}{ }^{2}$ are the values of the average standard errors in the groups before and after the experiment, calculated by formulas:

$$
m_{1}=\frac{D_{1}}{\sqrt{n_{1}}}, \quad m_{2}=\frac{D_{2}}{\sqrt{n_{2}}},
$$

where $D 1$ i $D 2$ are standard deviations;

$n 1, n 2$ are the number of respondents in the respective groups at the ascertaining and formative experiment stages.

Accordingly, after substitution of the received calculations data we have:

$$
t=\frac{\left|M_{2}-M_{1}\right|}{\sqrt{\frac{D_{2}{ }^{2}}{n_{2}}+\frac{D_{1}^{2}}{n_{1}}}}=5,054
$$

The tabular value of the Student's t-test ${ }^{14}$ at a given probability $(\mathrm{p}=0.01)$ and the degree of freedom $\left(\mathrm{d}_{\mathrm{f}}=\mathrm{n}_{1}+\mathrm{n}_{2}-2=58\right)$ is equal to $\mathrm{t}_{\mathrm{tab}}=2,663$, i.e. much less than $t=5,054$.

Thus, it is possible to draw a statistically substantiated conclusion that the differences in the average values of the civic competence levels in the experimental and control groups are not accidental and indicate the effectiveness of the pedagogical conditions introduction in the educational process of the pedagogical college.

Thus, the empirical data obtained in the research and experimental work process show that substantiated, developed and implemented in the

14 Румшинский Л. 3. Математическая обработка результатов эксперимента. Москва, 1971. 192 с. 
educational process of HEE pedagogical conditions for the civic competence formation of future primary school teachers are quite effective and can be successfully used in the educational process of pedagogical college.

The main study results, provisions and theoretical conclusions allow us to state that the introduction of certain pedagogical conditions within the simulated process of professional training of future primary school teachers contributes to the civic competence formation of future professionals.

\section{SUMMARY}

The article reveals the urgency of the problem of forming civic competence of future primary school teachers in the pedagogical college. Contradictions that actualize the research problem have been identified. The concept of "civic competence of primary school teachers" has been formulated. The pedagogical conditions of civic competence formation in future primary school teachers in the educational process of pedagogical college have been characterized. The generalized research results of forming civic competence levels of future primary school teachers have been presented. The comparative analysis of diagnosing formation results of future professionals' civic competence at the ascertaining and formative study stages have been conducted. It has been noted that the introduction of pedagogical conditions within the simulated educational process made it possible to increase the formation level of civic competence in students of the experimental group.

\section{REFERENCES}

1. Галузяк В.М., Сметанський М.I, Шахов В.I. Педагогіка : навчальний посібник. 2-е вид. випр. і. доп. Вінниця, 2003. 416 с.

2. Дубасенюк О.А. Інноваційні навчальні технології - основа модернізації університетської освіти. Освітні інноваиійні технології у процесі викладання навчальних дисциплін. Житомир, 2004. С. 3-14.

3. Кацова Л.Г. Організація педагогічної практики студентів в умовах інноваційного режиму школи. Педагогічні науки. Вип. 33. Херсон, 2003. С. 269-275.

4. Києнко-Романюк Л.А. Розвиток критичного мислення студентської молоді як загальнопедагогічна проблема : дис. ... канд. пед. наук. Київ, 2007. 209 с.

5. Леонова О. Образовательное пространство как педагогическая реальность. Alma таter (Вестник высшей школь). 2006. № 1. С. 36-40.

6. Нова українська школа : Концепція реалізації державної політики у сфері реформування загальної середньої освіти. URL: http://mon.gov.ua/\%202016/12/05/konczepcziya (дата звернення 03.08.2017).

7. Основні орієнтири виховання учнів 1-12 класів загальноосвітніх навчальних закладів України. Програма. Авторський колектив проекту: 
I. Д. Бех (кер. проекту та автор концептуальних засад) та ін. Тернопіль, 2008. $80 \mathrm{c}$.

8. Потопа К.Л. Соціально-педагогічні умови організації студентського самоврядування у вищих навчальних закладах : дис. ... канд. пед наук. Київ, 2006. 193 с.

9. Редько Л. Л., Чумичова Р.М. Теоретические подходы и проектирование образования в современных условиях. Ставрополь, 1996. 24 с.

10. Румшинский Л.3. Математическая обработка результатов эксперимента. Москва, 1971. 192 с.

11. Студентське самоврядування в Україні / Упоряд. Н. Демчук, Л. Кудіна. Київ, 2004. 60 с.

12. Терещук А.I., Дятленко С.М. Методика організації проектної діяльності старшокласників 3 технологій : методичний посібник для вчителів; навч. прогр., варіат. модулі. Київ, 2010. 128 с.

13. Швидкий С., Ступак О. Становлення та розвиток студентського самоврядування в України. Рідна шккола. 2014. № 3. С. 20-23.

14. Шендрик И. Г. Теоретические основы проектирования образовательного пространства субъекта. Екатеринбург, 2006. 198 с.

\section{Information about the authors: Hritchenko T. Ya.,}

Ph.D. in Pedagogic Sciences, Associate Professor, Associate Professor at the Department of Professional Methods and Innovative Technologies in Primary School Pavlo Tychyna Uman State Pedagogical University 2, Sadova str., Uman, Cherkasy region, 20300, Ukraine

Maidanyk O. V.,

Ph.D. in Pedagogic Sciences, Dean of Pedagogical Department Vinnytsia Humanities Pedagogical College 13, Nahirna str., Vinnytsia, 21019, Ukraine 